\title{
Signer's Gift - Rudolf Signer and DNA
}

\author{
Matthias Meili^
}

\begin{abstract}
In early May 1950, Bern chemistry professor Rudolf Signer traveled to a meeting of the Faraday Society in London with a few grams of DNA to report on his success in the isolation of nucleic acids from calf thymus glands. After the meeting, he distributed his DNA samples to interested parties amongst those present. One of the recipients was Maurice Wilkins, who worked intensively with nucleic acids at King's College in London. The outstanding quality of Signer's DNA - unique at that time - enabled Maurice Wilkins' colleague Rosalind Franklin to make the famous X-ray fiber diagrams that were a decisive pre-requisite for the discovery of the DNA double helix by James Watson and Francis Crick in the year 1953. Rudolf Signer, however, had already measured the physical characteristics of native DNA in the late thirties. In an oft-quoted work which he published in Nature in 1938, he described the thymonucleic acid as a long, thread-like molecule with a molecular weight of 500,000 to $1,000,000$, in which the base rings lie in planes perpendicular to the long axis of the molecule. Signer's achievements and contributions to DNA research have, however, been forgotten even in Switzerland.
\end{abstract}

Keywords: Bern · DNA · Double helix $\cdot$ History $\cdot$ Signer, Rudolf $\cdot$ Switzerland

\section{Signer's Early DNA Years}

\subsection{Introduction}

The search for the structure of nucleic acids had already occupied science for years prior to the 1953 discovery of the double helix by biologist James Watson and physicist Francis Crick. In 1869, the Swiss chemist Friedrich Miescher had discovered nucleic acids in Tübingen, Germany, where he had isolated them from salmon sperm. Then, just after the turn of the century, an entire series of researchers turned towards the chemical analysis of nucleic acids, among them especially the chemist Phoebus Aaron Theodor Levene, an American of Russian origin. Levene coined the so-called tetranucleotide hypothesis, according to which nucleic acids are built non-covalently from smaller units. These were the four bases cytosine, guanine, thymine, and adenine, four molecules of the pentose sugar deoxyribose (DNA) or ribose (RNA) as well as four phosphate residues. This is not the place to tell the entire story of the analysis of the chemical constitution of DNA [1].

${ }^{*}$ Correspondence: M. Meili

NZZ am Sonntag

Ressort Wissen

Falkenstrasse 11

$\mathrm{CH}-8021$ Zürich

Tel.: +4112581414

Fax: +4112582414

E-Mail: m.meili@nzz.ch
With the advancement of research, however, insight into the nature of macromolecules grew. This development was decisive in the discovery of the double helix structure and its central meaning in transmitting life. Regarding this change in paradigm, science historian Robert Olby in his important book 'The Path to the Double

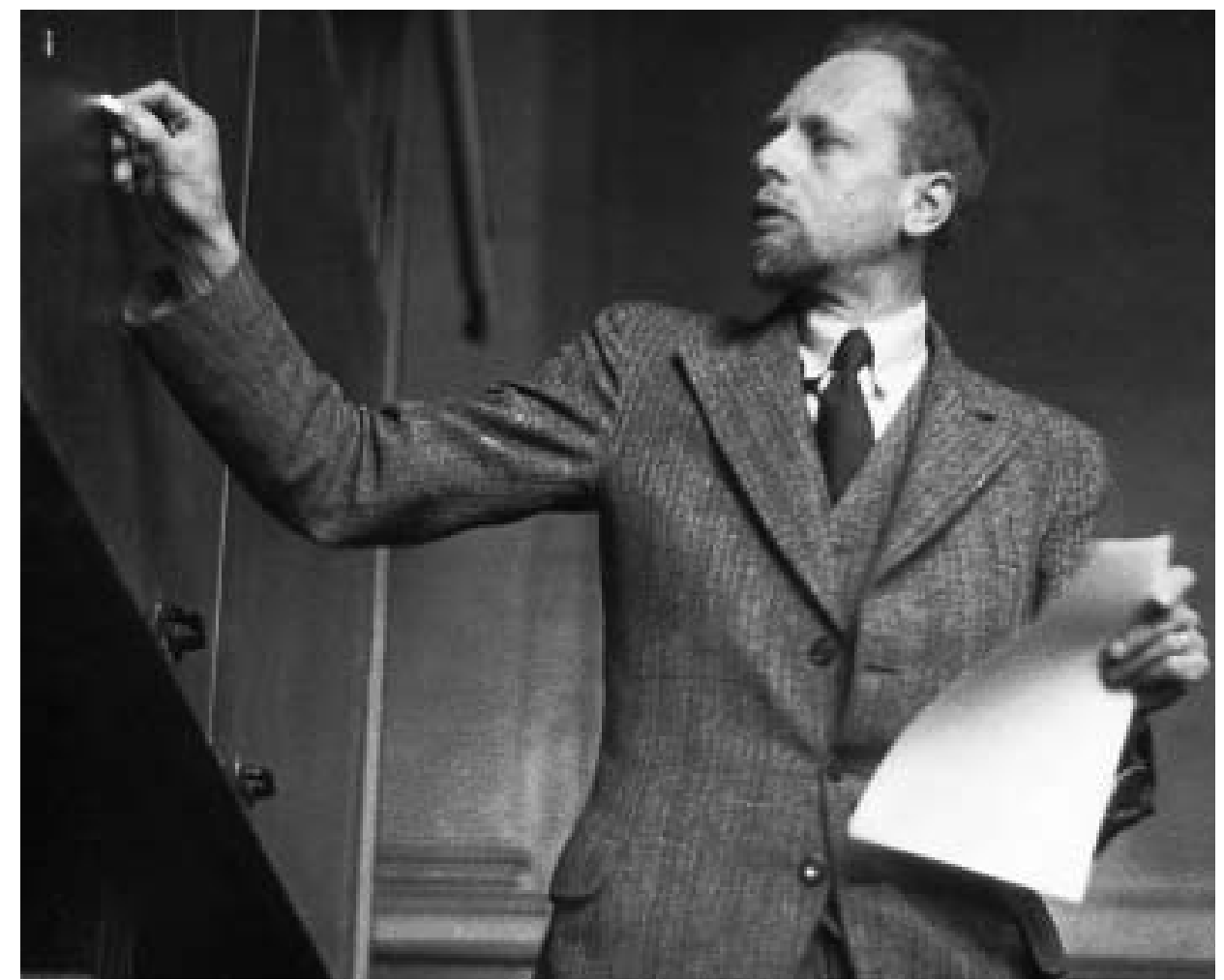

Helix', pointed out that Rudolf Signer made important contributions in two places: "It was no accident that the finest X-ray pictures of DNA available in 1953 had been taken using material supplied by a former student and colleague of Staudinger, Rudolf Signer" ([2] p.21). 


\subsection{Signer's Path Towards DNA Prior to 1938}

As a student of Hermann Staudinger, the pioneer of macromolecular chemistry, Signer was convinced of the existence of large macromolecules. Staudinger, who in the first part of his career worked on the organic synthesis of ketenes and polyketenes, had developed his ideas on the existence of high polymers primarily after his switch from the ETH Zurich, Switzerland to Freiburg-im-Breisgau, Germany. In 1924 when he was still active at the ETH Zurich, he became the first to use the term macromolecules and set out to prove the existence of these molecules through viscosity measurements [3]. Signer, who had followed Staudinger from Zurich to Freiburg in 1926, used his experimental measurements to help the idea on towards a breakthrough from a second direction. In particular, he developed and optimized the optical method used by Vorländer in the twenties for the measurement of flow birefringence and used it to measure the so-called homologous polymer rows of synthetic and natural polymers, especially the polystyroles and cellulose [4][5]. In flow birefringence, the dependence of optical behavior on flow conditions, concentration and the dissolved substance is examined. A solution of the substance is allowed to flow through a glass tube that is illuminated with a ray of light. The molecules orient themselves parallel to the direction of flow and the resulting anisotropy splits the light into two plane polarized beams. The longer the molecules are, the greater is the flow birefringence and the greater the difference between the refractive indices. Using this method in combination with measurements of viscosity and sedimentation rates, Signer was able to determine the form, size and molecular weight of macromolecules [6][7].

From flow birefringence, it had been shown in the thirties that some virus particles have a roughly spherical shape. Also from measurements of flow birefringence, Maurice Wilkins had gathered the first indications of the intra-molecular structure of DNA ([2], p. 16). The method is not very precise and has in the interim been replaced by better analysis procedures. However, it permitted making measurements quickly, which was important for materials that degrade rapidly, such as, for example, nucleic acids.

In 1933, thanks to a Rockefeller grant, Signer was able to spend half a year researching in Uppsala, Sweden, with Theodor Svedberg, who had developed ultracentrifugation in the twenties and thirties. Signer adapted this method to determining the molecular weight of macromolecules and was able to confirm his earlier results obtained from flow birefringence [7]. In all this early work, Signer upheld the macromolecular model and defended with word and deeds through which his passion for research is evident. Moreover, he had no fear of inter-disciplinary work. Indeed, one of his achievements was to help to introduce physical methods into organic chemistry.

In the early thirties, Signer was not yet working with DNA or chromosomes. However, Signer always had a special relationship with living nature. While still a student, he enthusiastically took part in natural science projects, and, in the excursions of the ETH botanist Carl Schröter, he was active as 'court photographer', as Signer himself later commented with pride. A beautiful collection of plant photographs that Signer later destroyed existed from this period ([8], p. 5). Signer continued to have a great love of flowers for the rest of his life, his favorite being the narcissus [9].

Signer's teacher, Hermann Staudinger, also saw his goal in the study of Nature's macromolecules. As known from various lectures, he firmly believed that the natural high molecular weight polymers had evaded chemical study up to that time because they were only able to exist under natural conditions and quickly decomposed in the laboratory [3]. It is not surprising that Signer, too, always lent great weight to the scientific observation of the substances that are important to life in animal and plant cells $[10]$

\subsection{An Astonishingly High Molecular Weight}

Signer was prepared when Torbjörn Caspersson came to Bern with a sample of thymonucleic acid to determine its molecular weight and shape. Depending on available sources, this should have been in the year 1936 ([2], p. 15) or 1937 ([8], p. 17).

Cell biologist Caspersson had been a student of Einar Hammarsten, who had worked on chromosome research since the early twenties. Hammarsten had isolated nucleic acids from calf thymus in 1924 and had described the product as "snowy white and of a curious consistency, like cotton wool'. Caspersson continued Hammarsten's work and noted with astonishment in 1934 that 'the complexes of nucleic acids must be larger than the protein molecules'. At this time, no important biological function was attributed to nucleic acids. According to the tetranucleotide hypothesis, they seemed to have too simple a structure for this. A repeating chain of similar nucleotide colloids seemed unable to direct such a complicated phenomenon as inheri- tance. According to Olby, Caspersson was thinking of a high-polymer molecule, even though he still spoke of 'complexes' in 1934. Nevertheless, Caspersson believed that the nucleic acids in the chromosomes had merely a supporting function for the proteins ([2], pp. 100-107). It is not known how far Signer thought then about the biological function. His later statements allow us to conclude that he guessed that nucleic acids had some biological significance ([8], p. 17). He was, however, not a cell biologist, but rather an organic chemist. With his research on polymers, he was active in a field that was new and contested from many sides.

Signer's method of flow birefringence had worldwide fame at that time, which was probably why Caspersson came to Bern. With this method it was possible to determine the ratio of the length to the diameter of a thread-like molecule. Indeed, "after half a day, we knew the molecular weight, and we wrote a small publication the next day", Signer said later in an interview for the Chemical Heritage Foundation ([8], p. 17). This work was published in January 1938 in Nature [11] and consisted of only about 400 words. From their measurements, Signer and Caspersson determined the viscosity and flow birefringence of thymonucleic acid in water and drew the following conclusions:

1) The molecules of sodium thymonucleic acid have the form of thin rods, whose length is approximately 300 times greater than their width.

2) The molecular weight lies between 500,000 and 1,000,000, in agreement with previous filtration and ultracentrifugation studies.

3) The flow birefringence was negative, indicating that the polarization plane is perpendicular to the longitudinal axis.

4) The optical anisotropy was very great, indicating that the molecules had strongly double-refracting components in a very definite pattern. Obviously, the publication states, the purine and pyrimidine rings lie in planes perpendicular to the long axis of the molecule.

Finally, it is stated that "these results will, it is hoped, be useful with reference to the chemical analysis of chromosome structure".

The publication was especially important because Signer, Caspersson and Hammarsten established such a high molecular weight for nucleic acid. Three months later, in a work also published in Nature, William Astbury and Florence Bell reached similar values with the aid of their first X-ray fiber diagrams of nucleic acids [12]. Their estimate was based on the density of DNA, the 


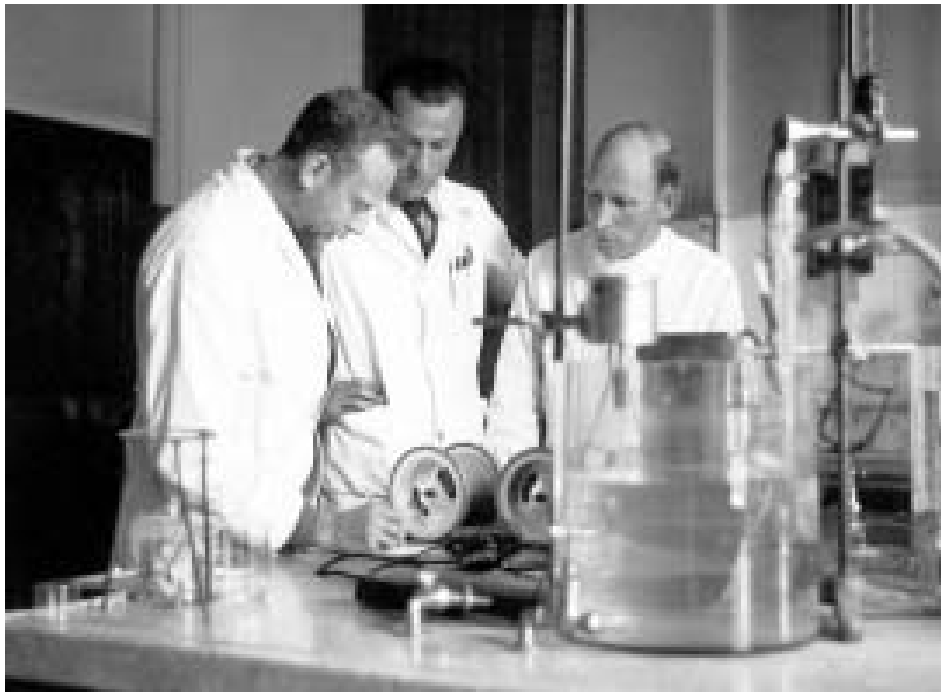

distance between nucleotides and the length-diameter ratio obtained from flow birefringence measurements. In the same year, in a paper in Science, Levene and Gerhardt Schmidt showed by ultracentrifugation, that native DNA had to be a large molecule [13]. However, in these experiments, in which thymonucleic acid was treated with depolymerases, molecules with a lower molecular weight were identified as smaller DNA molecules. This led to their continued belief in the tetranucleotide hypothesis, according to which DNA is a complex of smaller basic components ([2], p. 95)[3].

\section{Signer's Gift}

\subsection{Isolation of DNA}

Signer regarded this first determination of the molecular weight of DNA as his most important publication. From our perspective, however, this work created the prerequisite for a contribution that should be rated just as highly or perhaps even more highly: the provision of high-quality DNA samples which he donated to the scientific community.

Signer later said that after working with Caspersson in Bern, he had recognized how important nucleic acid was as a biological molecule ([8], p. 17). He could not yet know that it guided inheritance, since it was only in 1944 that Oswald Avery and his colleagues demonstrated with their legendary work with bacteria that nucleic acids are the 'transformation principle' [14], a result that became known only very slowly. Signer nevertheless recognized that the isolation of native DNA was an important prerequisite for further research on its structure. But the Second World War intervened. Signer served as a simple soldier, albeit very reluctantly, because he did not wish to neglect his research work ([8], p. 20). The double burden of military service and professorial duties led to myocardial infarction - a heart attack. His doctor prescribed half a year of rest. But after the war, when he read the results of the 1946 Cambridge Nucleic Acid Symposium to the Society for Experimental Biology ([2], p. 15)[15], Signer initiated an entire series of dissertations on the preparation of nucleic acid out of calf thymus.

The problem was that as soon as the cells were broken open, the nucleic acid rapidly decomposed. Using the method with which Hammarsten had prepared his nucleic acids in the twenties, the Bern researchers improved the technique of isolating DNA molecules with very long chains. Before the end of the forties, they were obtaining the qualitatively best DNA. In her biography of Rosalind Franklin, which was published last year, British science journalist Brenda Maddox referred to these samples as the 'manna of Bern' ([2], pp. 331-335)([16], pp. $156 \mathrm{ff}$.).

How was this achieved? In the first place, very gently. Signer and his doctoral students improved the process developed by Mirsky and Pollister, which Hammarsten had been already using in 1924. In a first step, the chopped calf thymus, which had been deep-frozen with dry ice immediately after slaughter, is mixed with a ten per cent sodium chloride solution while adding sodium fluoride to prevent the enzymatic decomposition of the deoxyribonucleic acid. In this way, the nucleoprotein is precipitated. In a second step, the protein is separated from the nucleic acid. This can take place in two ways - either the aqueous solution is mixed with chloroform and octyl alcohol leading to separation of the protein into the organic phase, or the Bang and Hammarsten process is followed, which, according to Signer, proved to be much simpler. In this process, the nucleoprotein acid solution is saturated with sodium chloride, whereupon the protein separates into a filterable form within a few days.

The nucleic acid that remains in the aqueous phase is precipitated with an alcohol/water mixture. The Bern researchers then cautiously removed any remaining protein by centrifugation. Finally the nucleic acid was precipitated from water with ethanol and dried at low temperatures in high vacuum. The combination of extreme care and patience was decisive. Attention had to be given to keeping the nucleic acid in an aqueous environment and carrying out all purification steps to the end. During the entire procedure, which took approximately three weeks, temperatures had to be kept close to $0{ }^{\circ} \mathrm{C}$. At the end, 700 grams of calf thymus yielded 5 grams of dried DNA sodium salt, a whitish, fluffy wad-like material [15][17].

\subsection{The Trip to London}

Signer's doctoral student Hans Schwander optimized the process developed by his predecessor Adolf Knapp. Viscosity measurements showed that Schwander's thymonucleic acid contained slightly larger molecules than Knapp's preparations, and much larger than the samples which Caspersson and Hammarsten had brought to Bern. In the period 1947-1949, Schwander isolated 50 grams of highly purified DNA. Signer took about 15 grams to London ([8], p. 18)[17], where a discussion under the title The physical-chemical properties and behavior of nucleic acids took place on May 12, 1950 [18].

The meeting was called by the Colloid and Biophysics Committee of the Faraday Society and organized by J.A.V. Butler and D.O. Jordan. It took place in the Institut Francais du Royaume-Unie in Queensberry Place. Before an audience of about 90 guests, Signer presented the results of his work with Schwander - a DNA with a molecular weight of 1 to 2 million that behaved like an unbranched linear molecule in solution. After the meeting, Signer gave samples of his best DNA to various interested parties among those present ([2], p. $332)([8]$, p. 18). It is now no longer possible to determine where all of Signer's DNA went. According to Raymond Gosling, a dozen groups were fortunate enough to obtain a sample of the high-quality material from Bern among them Maurice Wilkins, then at King's College in London [19].

It is certain that Gerald Oster and Denis Riley working at the Royal Institution in London, also investigated Signer's DNA. Using optical methods and viscosity studies, Oster estimated a molecular weight of 3.26 million for the Signer DNA [20]. Mol- 


\section{Signer's Career}

Rudolf Signer was born into a textile manufacturer's family on March 17, 1903 in Herisau, Switzerland. He was the youngest of five children. From 1909 to 1917, he attended the elementary and secondary school in his home community, then the high school in St. Gallen, Switzerland. Here, he completed his qualification for university entrance in 1921. He then studied at the ETH Zurich, Switzerland, in the Natural Sciences Department (Dept. X). He attended Hermann Staudinger's lectures in organic and inorganic chemistry. It was also Staudinger who supervised Signer's diploma work 'On Formaldehyde Diacetates' and supervised his diploma exam in the fall of 1925.

As his doctoral student, Signer continued to follow Staudinger when the latter was appointed to the University at Freiburgim-Breisgau, Germany, in 1926. In June 1927, Signer earned his doctorate with 'On the Constitution of Polyoxymethylene' as his topic. Shortly afterwards, he began to work on independent scientific projects in which he particularly sought to establish the existence of synthetic and natural macromolecular substances by optical measurement methods. In the fall of 1930, Signer began his teaching activity with the following lectures:

- Methods of preparative organic chemistry,

- Optical constants of organic compounds,

- Stereochemistry of organic compounds,

- Constitution and physical characteristics of organic compounds,

- Chemistry and colloidal chemistry of protein substances [a].

Signer married Charlotte Gretchen Meier from Rueschlikon, Switzerland, in Freiburg in 1928. Six children were born to the marriage.

With a grant from the Rockefeller Foundation, Signer was able to complete two six-month research terms in the laboratories of Theodor Svedberg in Uppsala, Sweden, and with Sir William Lawrence Bragg (the son of Sir William H. Bragg) in Manchester, England, in 1933. With Svedberg, he applied ultracentrifugation to synthetic macromolecular substances. With Bragg, he learned the methods of X-ray crystallography.

After the research residencies, Signer returned to Freiburg. Staudinger, who was to receive the Nobel Prize in 1953 for his achievements in the field of macromolecular chemistry, remained a lifelong honored teacher and later friend to Rudolf Signer. Later on, he was the only one of his colleagues who was permitted to visit Signer regularly at his house in Gümligen near Bern, Switzerland, as Signer completely separated his private life from his professional life [b].

In 1935, Signer was called to Bern at the age of 32 years. The university at that time had to choose between a classic color chemist and Signer for the teaching chair that was becoming available. In his proposal, the then dean of the Faculty of Natural Sciences showed that he was convinced that a new and modern direction should be taken. For this reason, he recommended that the Bern education executive should choose Signer's innovative and future-oriented field. In March 1935, Signer assumed his new post as an associate professor. He and his family moved to Gümligen, where he resided until his death. In 1939 he was named full professor and head of the then newly founded institute for organic chemistry in Bern [a].

Signer's works enjoyed early international recognition. In 1935, he was invited to Cambridge, England, to report on his research. In 1936, he received an invitation from the Royal Academy of Sciences in Amsterdam, Holland. In 1938, the American Rockefeller Foundation once more recognized his importance and promised him a grant of the then significant sum of 23,000 Swiss francs (Signer's annual income at the time being 9,447 Swiss francs) [a]. In 1948, thanks to a further Rockefeller grant, he spent a three-month research period in the USA. In 1949, he was awarded the Lavoisier medal by the Société Chimique de France. In 1953, he took part in the 9th Solvay conference in chemistry in Brussels on the subject of proteins. Signer was on the scientific committee of the Journal of Polymer Science. He published altogether 250 scientific works in the course of his career.

The ETH Zurich also recognized the importance of macromolecular chemistry, albeit rather late. Beginning in 1947, it engaged Signer for a one-hour lecture on the subject 'Problems of macromolecular chemistry' [c]. At that time, the ETH considered creating an institute for macromolecular chemistry, but for financial reasons, it just added a lecture for the higher semesters of the Chemistry Department (Dept. IV) and Natural Sciences Department (Dept. X). Typically, Signer complained after the very first lecture about the poor placement in the class schedule and demanded an improvement according to the importance of his subject.

Signer remained at the University of Bern until his retirement in 1972. During the years 1943/44 and 1957/58, he was the dean of the Faculty of Natural Sciences. His major experimental lecturing in organic chemistry made him widely known as an excellent lecturer [d]. He was also, however, a painstakingly exacting experimenter [e].

Very early on, Signer had filed a large number of international patents for various elaborate measuring instruments and cleaning methods for mixtures of chemical substances. Additionally, he functioned as an adviser to the Haco food company in Gümligen [b]. After his retirement, he devoted himself entirely to his books on philosophy, his family life and his biological garden at his home in Gümligen, where he died on December 1, 1990 at the age of 87 years.

[a] State archives, Bern; BB III b 647.

[b] P. Signer, Grüt/ZH, personal correspondence, January 2003

[c] ETH archives, Hs 971: 117.

[d] Der Bund, 17.3.1963, Bern periodical.

[e] M. Neuenschwander, Tentlingen/FR, personal correspondence, February 2003. 
ecular biologist Paul Doty in Harvard also obtained a sample. His light scattering measurements gave a molecular weight of 7 million [21]. Such figures were extraordinary high for those days. "No wonder it gave the best X-ray pictures!", Olby wrote ([2], p. 332).

\subsection{The Efforts Bear Fruit}

Maurice Wilkins wanted to carry out optical studies on Signer's DNA. In his Nobel Prize speech of 1963, he looked back on Signer's gift: "Every time I touched the DNA gel with a glass rod, I was able to pull out a thin and long fiber like a spider's thread. The perfection and evenness of the fibers allowed the speculation that the molecules were ordered in a regular fashion" [22].

Shortly after Wilkins had received the DNA, Raymond Gosling, his young colleague at King's College, made X-ray diffraction patterns from sheets of dried DNA gel with encouraging results. These highly pure samples allowed the DNA to adopt crystalline form under suitable conditions. In May 1951, Wilkins took some of the Xray pictures to a meeting at Naples, where James Watson saw them and changed the direction of his research to focus on DNA structure [19]. Wilkins gave the same Signer DNA to Rosalind Franklin and Gosling, who were able to establish the conditions to make even better X-ray fiber diagrams among them the now famous photograph No. 51, which provided James Watson and Francis Crick, at the Cavendish Laboratory in Cambridge, England, with the decisive pointer about the double helix nature of DNA.

During the time that this article was being written, Wilkins was, unfortunately,

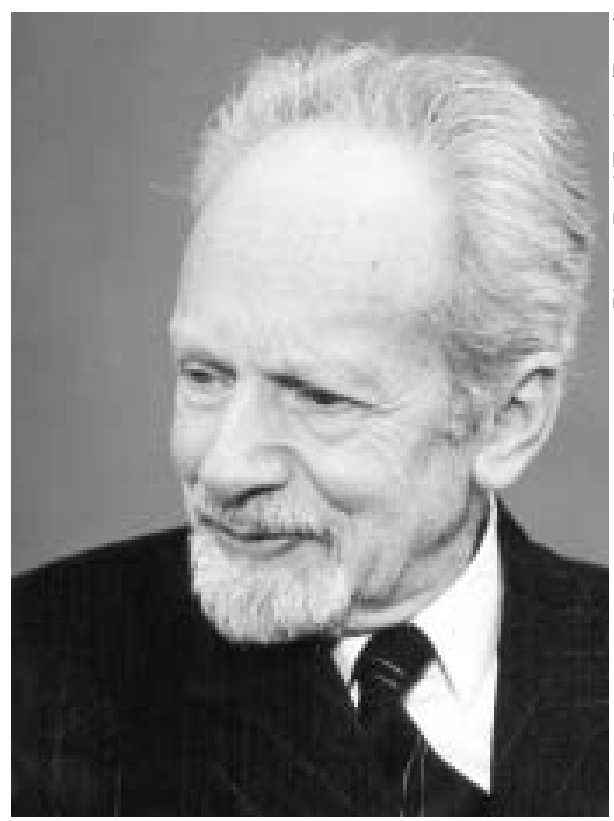

very ill and could no longer answer questions. But he has emphasized the quality of Signer's DNA: "One of the main reasons for which we obtained better refraction patterns than Astbury was that we had better DNA samples, made by Signer in Switzerland. In a certain way, this shows a founding principle of scientific advancement namely that one was dependent on the significant works of many chemists and biochemists" [23].

Gosling has not forgotten Signer's DNA and emphasizes Signer's role in the discovery of the DNA-double helix: "Without Signer, there would have been no DNA of this quality, and without this DNA there would not have been such good X-ray pictures, and without these, no discovery of the double helix. At least not by these persons at this time". Gosling also stresses Signers gift: "He acted rather in biblical terms in supplying the scientific community with his high-quality samples" [19].

\section{Signer After the Discovery of the Double Helix}

\subsection{Insights}

In later years, Signer devoted himself to the isolation and chemistry of proteins ([8], p. 21). He was aware that he had played an important role in the DNA structure and had possibly also missed an opportunity. Asked directly about a possible Nobel Prize, he dryly stated that his eccentricity of not choosing a main subject might have cost him the honor ([8], p. 17). To his student Markus Neuenschwander, he once observed that he had not realized it was possible to crystallize the DNA by pulling the fibers apart. This, he said, had been his error [24]. He might also have lacked the necessary technical support, and his research group the necessary size. According to Neuenschwander, Signer liked to develop his ideas in conversations with others, and emphasized time and time again how greato ly he had valued the discussions with Staudinger ([8], p. 8).

Whatever Signer began, he studied with intellectual sharpness and in fine detail, as long as his limited means at his small institute in Bern permitted. His interest in DNA thus continued well past 1953 . In 1958, together with doctoral student Peter Zürcher, he published a work in which he confirmed, with the aid of the sedimentation rate, the double helical structure of DNA [25].

On the occasion of his 70th birthday

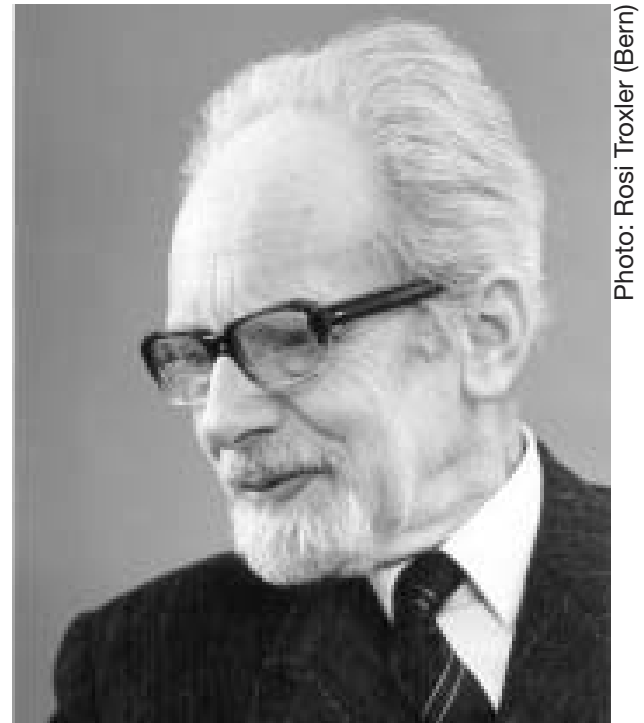

\subsection{Meaning in the}

\section{Swiss Research Landscape}

Signer's story reminds us that excellent and important research can take place even in smaller institutes. Protein and nucleic acid chemistry exploded in Signer's years, particularly in England and the United States. Scientists from all areas, chemistry, biology and physics, contributed. Signer had clear ideas within the frame of the knowledge of the time and within his possibilities and played an important, internationally recognized role. His work, however, has remained practically without resonance in Switzerland. In the opinion of prominent exponents of chemical research in Switzerland, his importance has been underestimated [26][27].

According to physical chemist Hans Kuhn, formerly director at the Max Planck Institute for Biophysical Chemistry in Göttingen, Germany, Signer has clearly received too little recognition. His classical measurements of flow birefringence, viscosity and sedimentation of dilute solutions of different macromolecules were fundamental for the development of theories about the shape and shape variations of fiber molecules. For young researchers in the area of organic chemistry and the developing field of biochemistry, however, not Bern but the ETH Zurich and the Universities of Geneva and Basel in Switzerland were the places where exciting research was being done [27]. Organic chemistry in Switzerland was under the spell of organic natural product chemistry, especially the chemistry of vitamins, steroid hormones, terpenes and alkaloids [26]. The Faculty of Natural Sciences of the University of Bern, however, put its bet on the future-oriented field of biopolymers with Signer at a time when 'no one else had even thought of it yet' in Switzerland [24]. Received: October 14, 2003 
[1] J.S. Cohen, F.H. Portugal, 'The Search for the chemical structure of DNA', Connecticut Medicine 1974, 38(10), 551-557.

[2] R. Olby, 'The Path to the Double Helix', Dover, New York, 2nd edition, 1994.

[3] Charles Scribner's Sons, 'Dictionary of Scientific Biography', 1970-1990, 13, 1-4.

[4] H. Staudinger, R. Signer, 'Über hochpolymere Verbindungen', Helv. Chim. Acto 1928, 11, 1047-1051.

[5] R. Signer, 'Über hochpolymere Verbindungen. Über die Strömungsdoppelbrechung der Molekülkolloiden', Z. Physik. Ch., A 1930, 150, 257-284.

[6] R. Signer, H. Gross, 'Über die Strömungsdoppelbrechung verdünnter Lösungen der Molekülkolloide', Z. Physik. Ch., A. 1933 , 165, 161-187.

[7] R. Signer, H. Gross, 'Ultrazentrifugale Molekulargewichtsbestimmungen an synthetischen hochpolymeren Stoffen', Helv. Chim. Acta 1934, 17, 335-351.

[8] Rudolf Signer, interview by Tonja A Koeppel at Bern, Switzerland, 30 September 1986 (Philadelphia: Chemical Heritage Foundation, Oral History Transcript \#0056)

[9] M. Meili, NZZ am Sonntag, 'Signer's DNA', 23. Februar 2003, p. 64.

[10] R. Signer, 'Zur Entwicklung der Wissenschaft der Makromoleküle', NZZ, 5. Mai 1964, Beilage Technik.

[11] FT. Caspersson, E. Hammarsten, 'Molecular Shape and Size of Thymonucleic Acid', Nature 1938, 141, 121.

[12] W.T. Astbury, F.O. Bell, 'X-Ray-Studies of Thymonucleic Acids', Nature 1938, $141,747$.

[13] G. Schmidt, P.A. Levene, 'The Effect of Nucleophosphatase on 'native' and depolymerized Thymonucleic Acid', Science 1938, 88, 172-173.

[14] O. Avery, C. MacLeod, M. McCarty 'Studies on the chemical Transformation of Pneumococcal Types', J. exp. Med. 1944, 19, 137-158.

[15] R. Signer, H. Schwander, 'Isolierung hochmolekularer Nukleinsäure aus Kalbsthymus', Helv. Chim. Acta 1949, 32 853-859.

[16] B. Maddox, 'The Dark Lady of DNA', Harper Collins, New York, 2002.

[17] H. Schwander, Riehen/BS, personal correspondence, February 2003.

[18] Meeting report. 'The physico-chemical properties and behavior of the nucleic acids', Transactions of the Faraday Society 1950, 790-795.

[19] R. Gosling, London, personal correspondence, October 2003.

[20] G. Oster, 'Fluorescence Quenching by Nucleic Acids', Transactions of the Faraday Society 1951, 47, 660-666.

[21] M.E. Reichmann, B.H. Bunce, P. Doty, 'The Changes Induced in Sodium Desoxyribonucleate by Dilute Acid', J. Poly. Sc. 1953, 19, 109-119.

[22] M. Wilkins, 'Nobel Lecture', 1963.

[23] M. Wilkins, 'The DNA Story', Special Collection, The Valley Library, Oregon State University, 1973, Video Transcript.

[24] M. Neuenschwander, Tentlingen/FR, personal correspondence, February 2003.
[25] R. Signer, P. Zürcher, 'Die Sedimentationsgeschwindigkeit konzentrierter Lösungen der Desoxyribonukleinsäure als Mittel zum Nachweis der Doppelmoleküle', Helv. Chim. Acta 1958, 31, $1958,47-52$

[26] A. Eschenmoser, ETH Zürich, personal correspondence, September 2003.

[27] H. Kuhn, Tschingel ob Gunten/BE, personal correspondence, October 2003. 